\title{
Blastic plasmacytoid dendritic cell neoplasm
} Neoplasia blástica de células dendríticas plasmocitóides

\author{
André Lencastre ${ }^{1}$ \\ Pedro Farinha ${ }^{4}$
}

\author{
Joana Cabete ${ }^{2}$ \\ Gilda Ferreira ${ }^{5}$
}

\author{
Alexandre João ${ }^{3}$ \\ Sara Lestre ${ }^{3}$
}

\begin{abstract}
Blastic plasmacytoid dendritic cell neoplasm is a rare and aggressive hematodermic neoplasia with frequent cutaneous involvement and leukemic dissemination. We report the case of a 76-year-old man with a 2 month history of violaceous nodules and a tumor with stony consistency, located on the head, and mandibular, cervical and supraclavicular lymphadenopathies. Multiple thoracic and abdominal adenopathies were identified on computerized tomography. Flow cytometry analysis of the skin, lymph node and bone marrow biopsies demonstrated the presence of plasmocytoid dendritic cell neoplastic precursor cells (CD4+, CD45+, CD56+ and $\mathrm{CD} 123+$ phenotype). After initial clinical and laboratorial complete remission with chemotherapy, the patient died due to relapse of the disease associated with the appearance of a cervical mass with medullary compromise. Keywords: Antigens, CD4; Antigens, CD56; Dendritic cells; Leukemia; Leukemic infiltration
\end{abstract}

Resumo: A neoplasia blástica de células dendríticas plasmocitóides é uma neoplasia hematodérmica rara, agressiva, com frequente envolvimento cutâneo e disseminação leucêmica. Relatamos o caso de um homem de 76 anos com quadro clínico com 2 meses de evolução caracterizado por nódulos e tumor de tonalidade violácea, de consistência pétrea, localizados na cabeça, e linfadenopatias mandibular, cervicais e supraclaviculares. Identificaram-se múltiplas adenopatias torácicas e abdominais em tomografia computorizada. A análise por citometria de fluxo de biópsias cutânea, ganglionar e óssea demonstrou a presença de precursores neoplásicos das células dendríticas plasmocitóides (fenótipo CD4+, CD45+, CD56+ e CD123+). Após remissão clínica e laboratorial completa inicial com quimioterapia, veio a falecer por recaída da doença associada ao aparecimento de massa cervical com compromisso medular.

Palavras-chave: Antígenos CD4; Antígenos CD56; Células dendríticas; Infiltração leucêmica; Leucemia

\section{INTRODUCTION}

Blastic plasmacytoid dendritic cell neoplasm (BPDCN) was originally recognized in 1994, but the subsequent lack of knowledge concerning its histogenesis led to a succession of different designations such as agranular CD4+ natural killer cell leukemia, blastic natural killer leukemia/lymphoma, agranular CD4+CD56+ hematodermic neoplasm or tumor. ${ }^{1-5}$ BPDCN is characterized by predominant cutaneous involvement with concomitant or ensuing spread to the bone marrow and peripheral blood. It has a very aggressive clinical behavior with short survivals.

\section{CASE REPORT}

A 76-year-old man was referred for evaluation of various cutaneous lesions. He had a prior history of total prostatectomy due to prostate adenocarcinoma 6 years before the current observation and myelodysplastic syndrome (MDS) presenting with neutropenia

Received on 22.12.2012.

Approved by the Advisory Board and accepted for publication on 13.01.2013.

* Work performed at the Hospital de Santo António dos Capuchos, Centro Hospitalar de Lisboa Central, EPE - Lisbon, Portugal.

Conflict of interest: None

Financial funding: None

MD - Resident Physician in Dermatovenereology - Dermatology Service, Hospital de Santo António dos Capuchos, Centro Hospitalar de Lisboa Central, EPE - Lisbon, Portugal

MD -Integrated Master's degree in Medicine - Resident Physician in Dermatovenereology - Dermatology Service, Santo António dos Capuchos Hospital, Hospital Center of Central Lisbon, EPE - Lisbon, Portugal.

MD - Eventual Assistant of Dermatovenereology - Dermatology Service, Hospital de Santo António dos Capuchos, Centro Hospitalar de Lisboa Central, EPE - Lisbon, Portugal.

MD - Hospital Assistant of Pathology Department - Service of Pathological Anatomy, Hospital de Santo António dos Capuchos, Centro Hospitalar de Lisboa Central, EPE - Lisbon, Portugal.

MD - Eventual Assistant of Hematology - Hematology Service, Hospital de Santo António dos Capuchos, Centro Hospitalar de Lisboa Central, EPE - Lisbon, Portugal.

C2013 by Anais Brasileiros de Dermatologia 
followed-up in hematology for 4 years. His neutropenia had been extensively studied through imaging studies and bone marrow aspirate and biopsy. MDS of the refractory cytopenia with multilineage dysplasia subtype was diagnosed and an expectant approach with careful observation was undertaken.

Two months before referral, he progressively developed multiple violaceous plaques and nodules on the face and scalp. He denied any constitutional symptoms and mentioned just a prior episode of minor head trauma. The physical examination revealed multiple well-demarcated, indurated plaques and nodules scattered throughout the right frontotemporal and biparietal areas as well as a $7 \mathrm{~cm}$ wide tumor in the anterior interparietal area (Figures 1 and 2). Several mandibular, cervical and supraclavicular lymphadenopathies were noted. He was otherwise well, which contrasted with the severity of the cutaneous findings. Laboratory results revealed hemoglobin 127 $\mathrm{g} / \mathrm{L}$, white blood cell count $6.0 \times 10^{\circ} / \mathrm{L}$ with $55 \%$ lymphocytes; an additional decrease in neutrophils $(0.7 \mathrm{x}$ $10^{\circ} / \mathrm{L}$ ) and platelet count of $241 \times 10^{\circ} / \mathrm{L}$ were noted. Lactate dehydrogenase was elevated at $1139 \mathrm{U} / \mathrm{L}$. Chest radiography was unremarkable. Thoracoabdomino-pelvic computerized tomography revealed enlargement of several mediastinal, axillary, celiac, retroperitoneal, obturator and inguinofemoral lymph nodes (some larger than $25 \mathrm{~mm}$ ).

Histology of skin and 2 cervical lymph nodes revealed a monomorphous, non-epidermotropic diffuse infiltration of small-to-medium sized cells with pleomorphic nuclei (Figure 3) in the skin. This dense infiltrate effaced the nodal architecture and was located in the dermis and hypodermis, separated from the epidermis by a grenz zone.

By immunohistochemistry, the cells coexpressed CD4, CD43, CD45 CD56, showed partial positivity for CD68 (Figures 4 and 5) and were negative for CD3, CD5, CD8, CD20, CD30, CD34, CD38, CD117, TDT, myeloperoxidase, light IgG chains and PAX5 (Figure 6). The proliferative index (Ki-67) was high, approximately $60 \%$.

Bone marrow biopsy showed a markedly hypercellular marrow, with CD4+, CD43+,CD45+, CD56+, CD123+ and HLA-DR+ small blast cells accounting for $80 \%$ of cellularity. No expressions of other T or B cell lineage were observed.

Based on clinical and laboratory findings, the patient was diagnosed with BPDCN with extensive cutaneous, nodal and bone marrow involvement.

Six cycles of CHOP (cyclophosphamide, adryamicine, vincristine, and prednisolone) were prescribed, with remission. Only post-therapy inflammatory reactive lesions remained on the face and scalp.

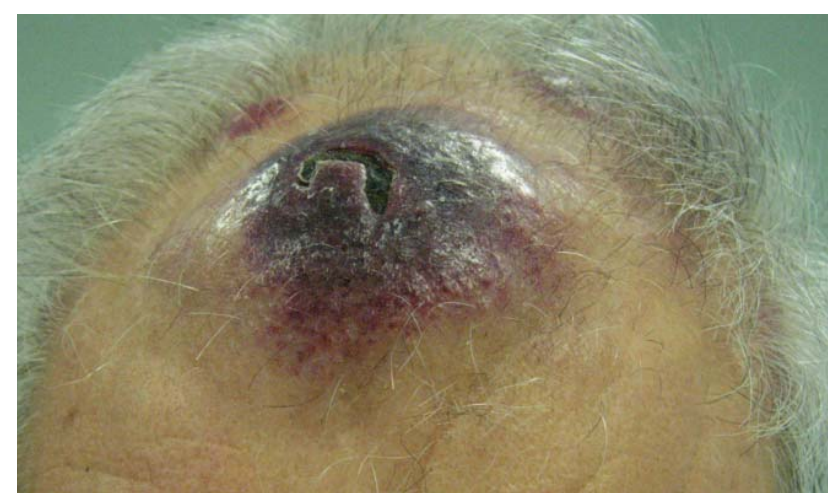

FIGURE 1: Violaceous, stony tumor in the anterior interparietal region

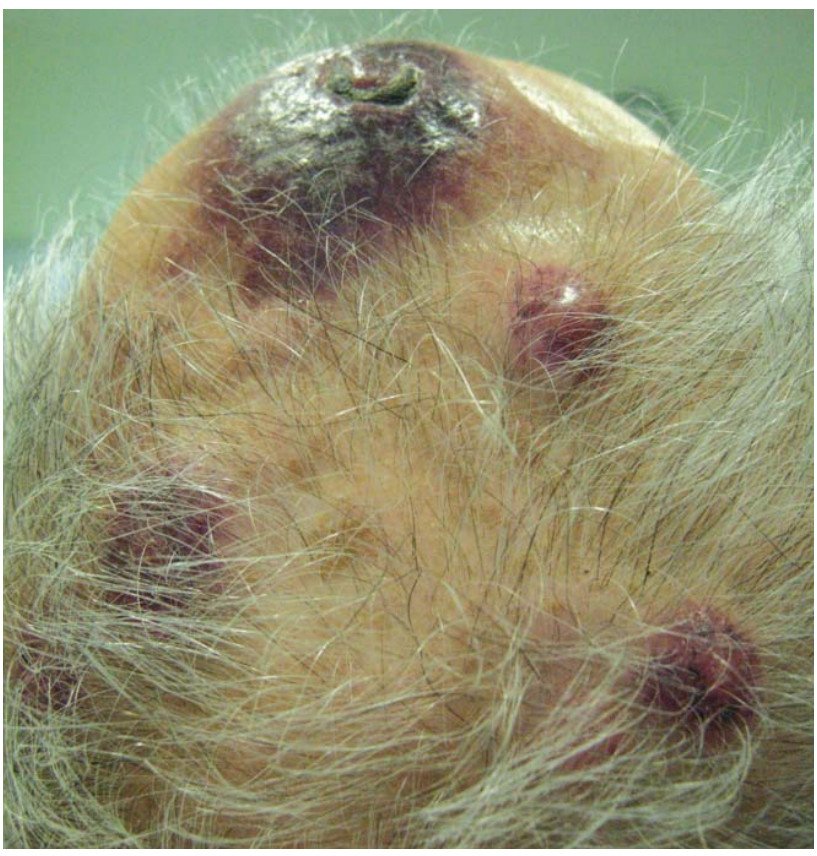

FIGURE 2: Multiple bilateral nodules and plaques in the parietal areas

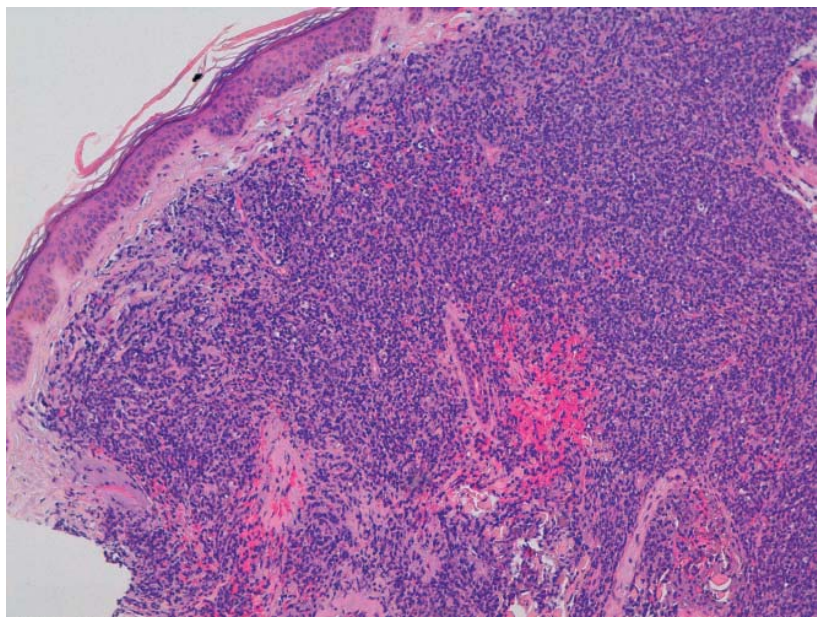

FiguRE 3: Histology of the interparietal tumor revealed compact, dermal and hypodermal infiltrate of non-epidermotropic monomorphous cells and blood extravasation (H\&E'100) 


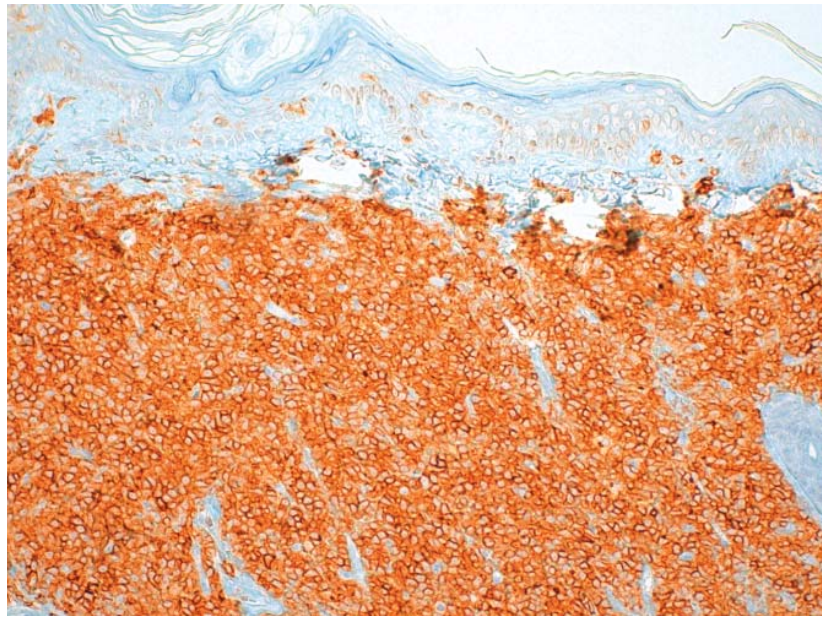

FIGURE 4: Diffuse infiltration by strongly positive tumor cells highlighting grenz zone $(C D 4 \times 200)$

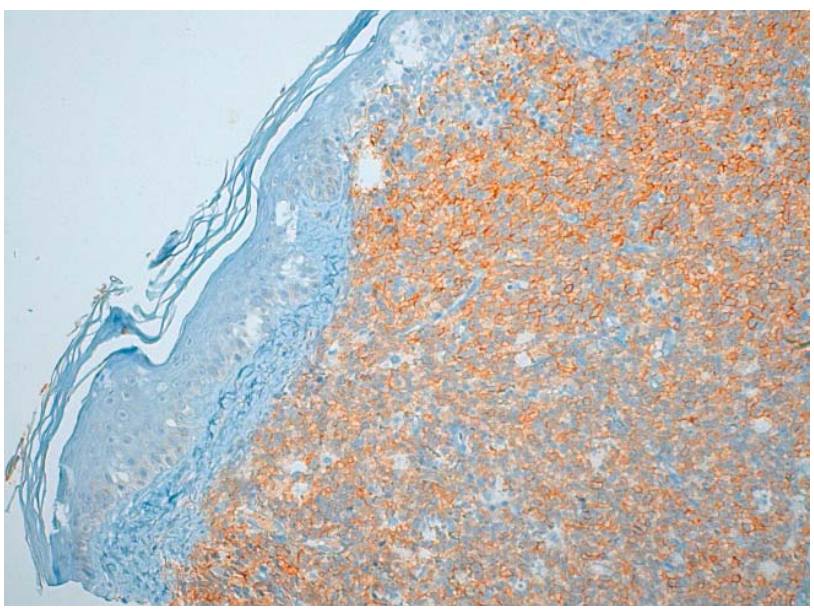

FIGURE 5: Diffuse infiltration by positive tumor cells $($ CD56 $\times 200)$

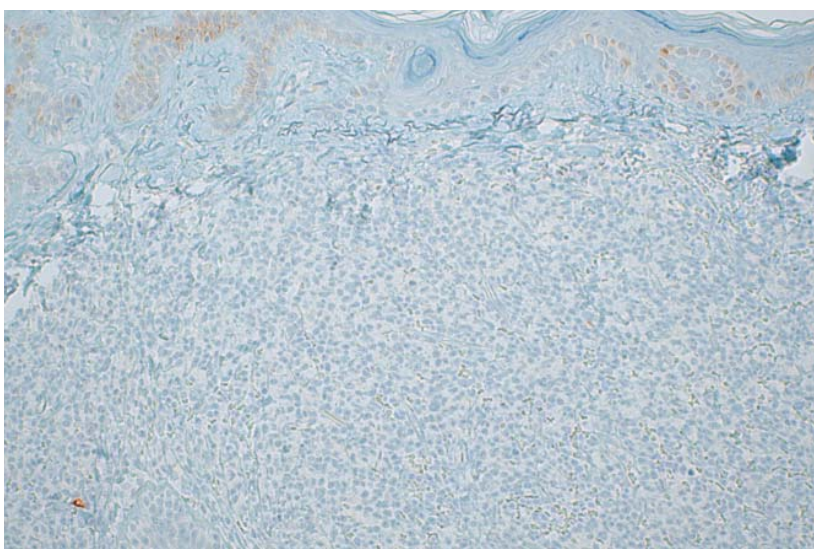

FIGURE 6: Diffuse infiltration by positive tumor cells $($ CD56 $\times 200)$

Two months later, the disease relapsed. Leftsided brachial monoparesis developed and a paravertebral cervical (C2-C3) mass with medullary compromise through the intervertebral foramen was detected on magnetic resonance imaging. The patient was hospitalized in a status of rapid progression of the dise- ase, with enlargement of the cervical mass, hyperleukocytosis $(>100.000 / \mathrm{ml})$, mental status deterioration and died 7 months after the diagnosis ( 9 months after onset of the first clinical symptoms).

\section{DISCUSSION}

The origin of BPDCN presumably lies in a hematopoietic precursor of plasmacytoid dendritic cells (DCs) of yet undefined lymphoid versus myeloid lineage. ${ }^{6-8}$

It is a rare disease, typically manifesting in middle-aged or elderly men (although pediatric cases have been reported). ${ }^{6}$ The clinical picture and progression of BPDCN consist of two main patterns. In $90 \%$ of cases, there is an indolent installation of cutaneous lesions followed later by dissemination, whereas in the remaining $10 \%$ it presents as advanced leukemia with systemic involvement from the start. Previous existence of MDS has also been reported in a few cases. ${ }^{6}$

The presence of multiple skin lesions is a feature of both patterns described, found in over $90 \%$ of BPDCN cases. ${ }^{3,6}$ Isolated skin lesions are also detected in over half of cases. ${ }^{3}$ Skin involvement may display a nodular or a patch and bruise-like lesion presentation, with a thicker neoplastic infiltrate in the former and a perivascular arrangement in the latter. ${ }^{3}$ In both cases, a diffuse and monomorphous dermal infiltrate of medium-sized cells, with an obvious blastic morphology and epidermal sparing is reported. ${ }^{9}$

The diagnosis requires the demonstration of CD4 and CD56, together with markers more restricted to plasmacytoid dendritic cells (such as CD123) and negativity for lymphoid, NK and myeloid lineageassociated antigens. ${ }^{4,8}$

In our patient's bone marrow flow cytometry, cells were CD4+, CD45+, CD56+ and CD123+ and lacked lineage-specific antigens. This phenotype, albeit with specific isoform CD45RA positivity, renders it highly specific, as published. ${ }^{10}$

Researchers debate whether tumor cells are originally sited in the bone marrow or skin. Unresolved questions remain regarding its histogenesis and aggressive clinical presentation that commonly affects both sites either consecutively or simultaneously. Furthermore, the existence of rapidly disseminating disease cases and those with primarily cutaneous disease and indolent progression raise questions to whether this represents two stages of a disease spectrum or 2 different CD4+CD56+ malignancies. ${ }^{6}$ Cutaneous tropism of blast cells may explain frequent skin localization. ${ }^{6}$

BPDCN has an aggressive clinical behavior despite an initial apparent indolence. The median survival is approximately $12-14$ months.

Cognizant of our patient's age, CHOP chemotherapy was undertaken. The patient initially 
responded favorably, as described in the literature. ${ }^{3,6}$ As also reported, he had a fast and aggressive relapse and died in a state of hyperleukocytosis $\left(>100 \times 10^{9} / \mathrm{L}\right)$ with a symptomatic central nervous system lesion, deemed secondary to his BPDCN.

Currently, there is no apparent consensus for the optimal treatment of BPDCN. Intensive therapy for acute leukemia increases the rate of sustained complete remission. However, only myeloablative treatment with allogenic bone marrow transplantation within the first remission has resulted in a better chance of longer survival. ${ }^{6}$

\section{REFERENCES}

1. Facchetti F, Jones D, Petrella T. Blastic plasmacytoid dendritic cells neoplasm. In Swerdlow S, Campo E, Vardiman J, editors. WHO classification of Tumours of Haematopoietic and Lymphoid Tissues. 4th ed. Lyon: International Agency for Research on Cancer; 2008. p. 145-7.

2. Adachi M, Maeda K, Takekawa M, Hinoda Y, Imai K, Sugiyama S, et al. High expression of CD56 (N-CAM) in a patient with cutaneous CD4-positive lymphoma. Am J Hematol. 1994;47:278-82

3. Petrella T, Bagot M, Willemze R, Beylot-Barry M, Vergier B, Delaunay M, et al. Blastic NK-Cell Lymphomas (Agranular CD4+CD56+ Hematodermic Neoplasms). Am J Clin Pathol. 2005; 123:662-75.

4. Facchetti F, Ungari M, Marocolo D, Lonardi S, Vermi W. Blastic plasmacytoid dendritic cell neoplasm. Haematol Meet Rep. 2009;3:1-3.

5. Sanches Jr J, Moricz C, Festa Neto C. Lymphoproliferative processes of the skin: part 2 - cutaneous T-cell and NK-cell lymphomas. An Bras Dermatol. 2006;81:7-25.

6. Feuillard J, Jacob MC, Valensi F, Maynadié M, Gressin R, Chaperot L, et al. Clinical and biological features of CD4+ CD56+ malignancies. Blood. 2002;99:1556-63.

7. Petrella T, Comeau MR, Maynadié M, Couillault G, De Muret A, Maliszewski CR, et al. Agranular CD4+ CD56+ hematodermic neoplasm (blastic NK-cell lymphoma) originates from a population of $\mathrm{CD} 56+$ precursor cells related to plasmocytoid monocytes. Am J Surg Pathol. 2002;26:852-62.

8. Piña-Oviedo $\mathrm{S}$, Herrera-Medina $\mathrm{H}$, Coronado $\mathrm{H}$, Del Valle $\mathrm{L}$, Ortiz-Hidalgo $\mathrm{C}$. $\mathrm{CD} 4+/ \mathrm{CD} 56$ + hematodermic neoplasm: presentation of 2 cases and review of the concept of an uncommon tumor originated in plasmacytoid dendritic cells expressing CD123 (IL-3 receptor alpha). Appl Immunohistochem Mol Morphol. 2007:15:481-6.

9. Petrella T, Dalac S, Maynadié M, Mugneret F, Thomine E, Courville P, et al. CD4+ CD56+ cutaneous neoplasms: a distinct hematological entity? Groupe Français d'Etude des Lymphomes Cutanés (GFELC). Am J Surg Pathol. 1999; 23:137-46.

10. Trimoreau F, Donnard M, Turlure P, Gachard N, Bordessoule D, Feuillard J. The CD4+ CD56 + CD116- CD123 + CD45RA + CD45R0- profile is specific of DC2 malignancies. Haematologica. 2003;88:ELT10.

\author{
MAILING ADDRESS: \\ André Lencastre \\ Alameda de Santo António dos Capuchos \\ 1169-050 - Lisboa - Portugal \\ E-mail: lencastre.derm@gmail.com
}

How to cite this article: Lencastre A, Cabete J, João A, Farinha P, Ferreira G, Lestre S. Blastic Plasmacytoid Dendritic Cell Neoplasm. An Bras Dermatol. 2013;88(6 Suppl 1):S158-61. 